\title{
Videoconference in Academic Tutoring: A Case Study
}

\author{
Fátima Margarita Castro León ${ }^{1}$, José $\mathrm{M}^{\mathrm{a}}$ del Castillo-Olivares Barberán ${ }^{1}$, David Pérez-Jorge ${ }^{1}$, Juan José Leiva \\ Olivenza $^{2}$ \\ ${ }^{1}$ Department of Didactics and Educational Research, Faculty of Education, Universidad de La Laguna (ULL), \\ Tenerife, Spain \\ ${ }^{2}$ Department of Didactics and Scholar Organization, Faculty of Education, Universidad de Málaga (UMA), \\ Málaga, Spain
}

Correspondence: David Pérez-Jorge. Faculty of Education, Department of Didactics and Educational Research. Universidad de la Laguna (ULL), Tenerife, Canary Islands, Spain. E-mail: dpjorge@ull.edu.es

Received: November 4, 2017 Accepted: December 20, $2017 \quad$ Online Published: January 29, 2018

doi:10.5539/ass.v14n2p49

URL: https://doi.org/10.5539/ass.v14n2p49

This paper is the result of the call for innovation in virtual tutoring 2016.

\begin{abstract}
The use of the videoconference as a resource for academic tutoring is starting to spread as a useful practice. From a pedagogical point of view this technological innovation involves many uncertainties as regards its organization, its technology and its pedagogical features. In this paper we study this process in the Degree of early childhood education at the University of La Laguna in the academic course 2016, where two hundred students experienced the video tutorials in two subjects. We will prove how students enter university with previous experiences related to the use of videoconferences in different usage models. In this paper we reflect on decision making processes carried out in several categories. We conclude with the assessment that students have made about this experience, highlighting here the specific utility as regards the most effective type of feedback and the relational environment.
\end{abstract}

Keywords: Videoconference, academic tutoring, synchronous communication, video-tutoring, university teaching, technological innovation

\section{Introduction}

\subsection{The use of videoconference as an emerging technology at university}

The application of emerging technologies in academic life, as in the case of videoconference applied to tutoring, offers, from a pedagogical point of view, an excellent opportunity to study how such technologies affect and contribute to the development of the educational system and how they relate to teaching improvement processes and their implementation difficulties. (Aguaded, 1996; Ambròs, 2011; Martínez, 2003)

Videoconference is an emerging technology. Actually, we performed personal videoconferences in the late 90s (Webster, 1998) with less consistent technologies such as Messenger, i-Visit, or Netmeeting with the hardware limitations of that time. Therefore, its experimentation was very difficult and there were very few users with the necessary conditions to participate. (Marín \& Salinas, 2015; Henderson \& Philips, 2015; Castillo-O \& Castro, 2013)

The technological explosion in the first decade of the millennium has resulted in conditions which did not previously exist. Fifteen years later, high-speed networks have become widespread in society, and videoconference appears as a basic mobile communication system.

Currently we live in a situation where students at the university demand the use of the resources available to facilitate academic requirements, new forms of collaborative work and new study programmes in terms of competences, autonomous work and continuous assessment. However, as noted by several authors such as Area and Guarro (2013) or Barroso and Cabero (2013), the use of videoconference is usual in proposals based on e-Learning processes and virtual conferences, webinars, and other uses designed for institutional relations and communication proposals. We live in a time of uncertainty as regards this phenomenon. What does the videoconference add? will we see its expansion in university tutoring and counselling?, in which context are we 
situated to promote this change?

In fact, the academic times which we share nowadays are characterized by the emphasis on training and skills, a growth in collaborative ways of working on projects; a function of tutoring and counseling as a key to academic success; and constant process of innovation and experimentation of innovative models to work in network communities.

In this context, the use of videoconference is becoming an interesting promise (Barroso \& Cabero, 2013). Therefore, our university tries, in the academic course 2016, to institutionalize an innovation project of formal tutoring using telematics means, as a formal appeal and support for experimentation.

We are evaluating the videoconference to complement the usual face-to-face tutoring sessions, since it is one of the tools of communication that allows, among others, a two-way communication process among participants and also can be performed regardless of where we are. Our insular geography claims alternatives and solutions for a geographical dissemination, which at certain times of the academic course can be reflected in a lack of class attendance and none contact with the teacher (long holiday periods, holiday preludes, carnivals, Christmas time and other holidays).

The aim of this project is to promote and support the pedagogical integration of ICT and in particular tools that enable online communication with students, as a resource for e-tutoring teaching developed in the Degree of Early Childhood Education. Its aim is to promote a communication model which favours constructive and collaborative knowledge processes through the use of spaces and digital tools by both teachers and students. In this sense, this institutional project aims to promote actions such as the cited below:

- Experience, apply and reflect on the use of videoconferencing applied to teaching and tutoring activity.

- Evaluate the impact of these digital resources on improving teaching through opinion questionnaires of the students involved.

- Train students as future teachers in the educational use of these resources.

It is in this context where our study is situated. From a perspective of action research, teachers of Instructional Technology Basics, assume the objectives of this institutional initiative. It is an opportunity to study the phenomenon from a pedagogical point of view, sensitive to change processes, to the contexts of innovation and educational improvement.

\subsection{Videoconference in academic tutoring as a problem to study}

This is a novelty which can be analysed from different approaches: from processes of change or innovation (Area \& Guarro, 2013); or from an organizational point of view (Martinez 2003); or from the technological (Henderson \& Philips, 2015), or the methodological approach or pure effectiveness of tutoring, and an economic or legal-based approach.

We discover new pedagogical questions:

- Questions focused on the educational: How is the communication model? How does the context affect this communication? Does the videoconference allow me to do more and better tutoring sessions? Will students discuss different issues from those they treated in conventional tutoring? When and which topics will they discuss? Will they be more effective?

- Questions focused on the innovative power: What degree of duration and continuity will the tutoring relationship have through the videoconference? Will I achieve a better impact on tutoring? Does it bring improvements in tutoring relationships?

- Questions focused on technological proposals: What tools do we need? Which technological requirements are necessary? and which requirements of habituation are essential?

- Organizational questions: How many types of videoconferences are there? How is the best organizational model? Is it individual or collective?

- Issues related to professional competence: Is it recognized as a professional competence? Does it provide new communication environments susceptible to teaching and skills?

Therefore, we would like to emphasize the fact that this will be in the future a topic of discussion since central to this debate is the fact that blended learning methodology involves improvements. Distance learning maximizes its quality when it assumes face-to-face experiences, when it is combined with face-to-face teaching. Furthermore, it seems that it does so at the same speed as face-to-face teaching maximizes its quality adopting on 
line processes of formative responsibility such as autonomous or independent work and the teaching based on the student.

In our study we have made a selection of three of these priority issues which we think are the most relevant:

- Identify and experiment with different models of tutoring through videoconference.

- Identify the technological and educational elements in the experience of tutoring through videoconference.

- Know the students' opinions.

Therefore, we recognize there seems to be a fertile field of research and seeking firstly clarity and simplicity, it seems appropriate to select basic questions to help us understand how this fusion between videoconference and tutoring works and know models, elements and assessment of the members.

\section{Method}

We have set a different technique according to the objective of the study:

- We have performed a literature review and an assessment of two different groups in order to identify and test the different models.

- We have carried out a qualitative analysis based on the participants' observation, a field diary and a discussion group in order to identify the technological and pedagogical elements.

- We performed a quantitative descriptive analysis and a heuristic analysis of the questionnaire responses once the experience was over in order to carry out the assessment of students.

\section{Results}

\subsection{Different models of tutoring by videoconference}

Videotutoring is a synchronous communication planned for teaching purposes which takes place by means of easily accessible technologies.

Videotutoring is made up of 4 components. The components that make it possible are (Martinez, 2003) the following ones: the teachers, the students, their functional relationship, and the technological components.

Logically, the four components have a valuable diversity. However, the component that determines the model is the relational component and, in this sense, we can observe 6 possible relational formats (Figure1 and Table 1).

We made videotutoring experiences using the $\mathrm{T} 1$ and $\mathrm{T} 5$ formats. $\mathrm{T} 5$ format was basically used since it implies an interactive communication in small groups.

In this sense, we can observe that students support one another and their telematic skills can be balanced. The small working group is a basic characteristic to work in teaching and almost all practical sessions are organized in this way.

This means that, apart from the common difficulties of collaborative work related to management of human groups, expectations, leadership or coordination, there exists the physical difficulty of working together since it imposes common working hours which sometime are impossible to fulfill.

We think that videoconference is expected to be incorporated to the telematic studying habits of our future students.

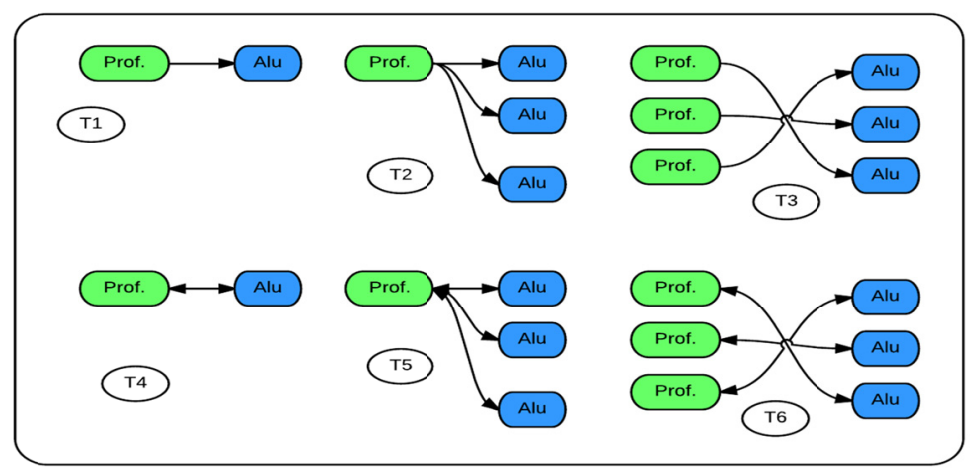

Figure 1. Typology of videotutoring as relational structure 
Table 1. Models of tutoring by videoconference

\begin{tabular}{ccc}
\hline $\begin{array}{c}\text { T1- Type 1: a one-way expository } \\
\text { communication from teacher to student } \\
\text { or from student to teacher }\end{array}$ & $\begin{array}{c}\text { T2- Type 2: a one-way expository } \\
\text { communication is performed from the } \\
\text { teacher to many students }\end{array}$ & $\begin{array}{c}\text { T3- Type 3: a one-way expository } \\
\text { communication is performed from } \\
\text { several teachers to several students }\end{array}$ \\
\hline $\begin{array}{c}\text { T4- Type 4: a two-way or interactive } \\
\text { communication is performed between } \\
\text { teacher and student }\end{array}$ & $\begin{array}{c}\text { T5- Type 5: a bidirectional expository } \\
\text { communication is performed to many } \\
\text { students }\end{array}$ & $\begin{array}{c}\text { T6- Type 6: A two-way communication } \\
\text { between several teachers and several } \\
\text { students is performed }\end{array}$ \\
\hline
\end{tabular}

\subsection{Technological, organizational and pedagogical elements of experience}

Trying to clarify the different ways of making decisions and those elements which interrelate in the experience of videotutoring, we think it is useful to specify three dimensions: technological, organizational and pedagogical dimensions.

Within the technological dimension we can find decisions about software and hardware devices involved. In the organizational dimension, we find those issues related to space, time and rules regulations, whereas in the pedagogical dimension we find issues related to education, skills and competencies.

Then, we will observe the relationship among decisions made according to dimensions in each of the subjects.

a) Decisions about technological elements for videotutoring

The first level of decisions is made up by technological decisions, since they provide the channel that makes the transmission possible. The installation of wireless internet connection throughout the university and the agreement with Google Enterprise to create an academic account for each student is one of the key factors for this experience.

The following table describes essential technological elements for the development of videotutoring.

Table 2. Technological elements for the development of videotutoring

\begin{tabular}{|c|c|c|}
\hline & Subject Semester 1 & Subject Semester 2 \\
\hline Videoconference Pack & $\begin{array}{c}\text { Camera, headphone and standard hearing aid for } \\
\text { windows }\end{array}$ & $\begin{array}{c}\text { Camera, headphone and standard hearing aid } \\
\text { for windows }\end{array}$ \\
\hline Software for videotutoring & institutional accounts associated with gmail & institutional accounts associated with gmail \\
\hline Infrastructure & $\begin{array}{c}\text { Institutional wifi installation with } 50 \text { meter repeaters } \\
\text { in all buildings in the faculty. Variable signal } \\
\text { intensity depending on access point }\end{array}$ & Use of network cable \\
\hline Laptop computers & $\begin{array}{l}\text { Students use their own resources and those assigned } \\
\text { by the library. }\end{array}$ & $\begin{array}{l}\text { The teacher installs in a classroom a laptop } \\
\text { computer with cable network }\end{array}$ \\
\hline Computer rooms & $\begin{array}{c}\text { Computer rooms with cable networks are used at } \\
\text { their discretion. }\end{array}$ & They are not used \\
\hline
\end{tabular}

There are other tools used, such as shared whiteboards, map editors concepts or different format files that are used spontaneously depending on the content of the tutorship.

b) Decisions on organizational elements for videotutoring

Without specific organization of space, time and groups it would be impossible to allow a synchronous coincidence of activities. In the experience we studied, we made the following decisions (Table 3)

Table 3. Technological elements for the development of videotutoring

\begin{tabular}{|c|c|c|}
\hline & Subject semester 1 & Subject semester 2 \\
\hline Coordination & $\begin{array}{l}\text { Bimonthly, monitoring phase between } \\
\text { participating teachers }\end{array}$ & Bimonthly, monitoring phase between participating teachers \\
\hline Time & $\begin{array}{l}\text { For one month prior appointment system, } 10-20 \\
\text { minutes per connection. }\end{array}$ & $\begin{array}{l}\text { For a week, according to rigorous prior appointment list, } 10 \\
\text { minutes per connection. }\end{array}$ \\
\hline Space & The students determine the place & $\begin{array}{l}\text { Conditioned classroom with laptop computer connected by } \\
\text { cable network and available in a hemicycle, each group } \\
\text { continues in video tutoring. }\end{array}$ \\
\hline Group & The same class groups, 3 to 5 & The same class groups, 3 to 5 . \\
\hline
\end{tabular}

c) Decision-making on pedagogical elements for videotutoring

This is the richest dimension, from an academic point of view, since it includes aspects that justify and rescue from videotutoring an experience that would become innovative, beyond a new experience, and able to provide a 
greater improvement for the educational process.

It is also a dimension which is characteristic of the teaching relationship since the teacher plans the experience taking into account its educational utility. For this reason, this dimension has its own particular characterization for each subject.

Table 4. Elements for the development of videotutoring

\begin{tabular}{|c|c|c|}
\hline & Subject semester 1 & Subject semester 2 \\
\hline Activity & \multicolumn{2}{|c|}{$\begin{array}{l}\text { To perform a videoconferencing tutoring } \\
\text { with the teacher at times and in places } \\
\begin{array}{ll}\text { different from the conventional ones. } & \text { early detection of learning difficulties }\end{array}\end{array}$} \\
\hline Aim & $\begin{array}{l}\text { To experience apply and reflect on } \\
\text { university teaching with the use of } \\
\text { videoconferencing (hangout, } \\
\text { webcam ...). }\end{array}$ & $\begin{array}{c}\text { To learn to plan and organize group presentations. } \\
\text { To express the main ideas and aspects of interest of the task } \\
\text { To experience different communicative situations and the defence of } \\
\text { the project }\end{array}$ \\
\hline Resources & The student's laptop computer & $\begin{array}{l}\text { Shared online presentation. Previous video which shows the case to } \\
\text { be evaluated, previous report of the practical lesson already } \\
\text { evaluated. Use of shared whiteboard for visual explanation }\end{array}$ \\
\hline & & $\begin{array}{l}\text { The presentation and defence is a category included in the evaluation } \\
\text { rubric of this activity. It is evaluated by means of } 4 \text { levels: }\end{array}$ \\
\hline \multirow[t]{2}{*}{ Evaluation } & \multirow[t]{2}{*}{$\begin{array}{l}\text { Autonomy, effectiveness, clarity, order, } \\
\text { punctuality and participation in the } \\
\text { videoconference will be assessed. }\end{array}$} & $\begin{array}{l}\text { 1-No } \\
\text { 2-Weak and disjointed. } \\
\text { 3-It adequately reflects what was requested. It is also understood and } \\
\text { correct. }\end{array}$ \\
\hline & & 4-It presents excellent added values \\
\hline $\begin{array}{l}\text { Atmosphere } \\
\text { (Relations) }\end{array}$ & $\begin{array}{l}\text { With enthusiasm and motivation, with } \\
\text { jokes and some anxiety for novelty, } \\
\text { during a couple of weeks the students } \\
\text { look for spaces in the benches of the } \\
\text { corridors, tables and carrells in the library } \\
\text { in order to perform the practice. }\end{array}$ & $\begin{array}{l}\text { The different groups perform their presentations in the classroom } \\
\text { they are used to, where practices were performed. They have } \\
\text { prepared their presentations, take notes in their hands and sometimes } \\
\text { they read. The atmosphere is relaxed and sometimes the "teacher" } \\
\text { yseems not to be present for them. They speak about the teacher using } \\
\text { the personal pronoun "he", as if he was not there. }\end{array}$ \\
\hline $\mathrm{Ob}$ & \multicolumn{2}{|c|}{$\begin{array}{l}\text { It has been necessary to arrange a very } \\
\text { precise appointment calendar for tutoring The experience with the videoconference has been similar in style to } \\
\text { s sessions. The number of students is very those videoconferences performed among distant working groups. } \\
\text { large and therefore the number of } \\
\text { videoconferences is overwhelming. There are no technical difficulties. }\end{array}$} \\
\hline
\end{tabular}

\subsection{Assessment of students}

The evaluation of the students' experience is a key factor in the final decision of the continuity and approach to future challenges and changes.

Previous experience in video
$89 \%$ of the sample says that they have previously
performed videoconferences.

$11 \%$

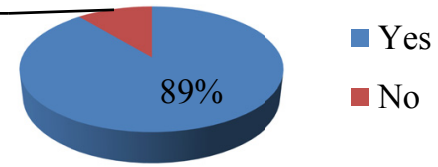

Figure 2. Previously performed videoconferences.

Context of use

$30 \%$ of these experiments were carried out with teachers, virtually the same amount as with friends. The remaining third of experiences is divided into family and classmates.

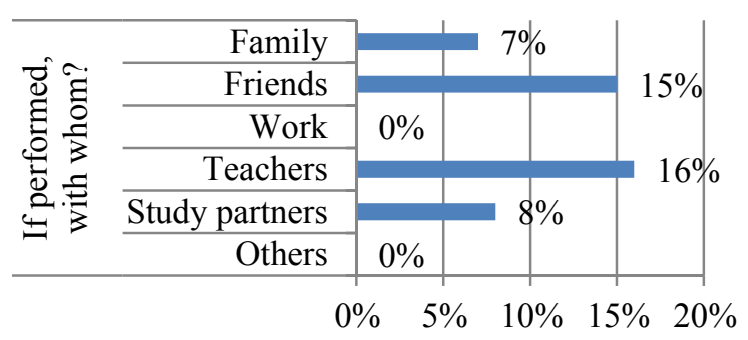

Figure 3. Context of use 
Used tools

The most widespread used tool among our students is the hangout (Gtalk), with $64 \%$, followed by Skype with $20 \%$ and $12 \%$ messenger.
If performed: How?

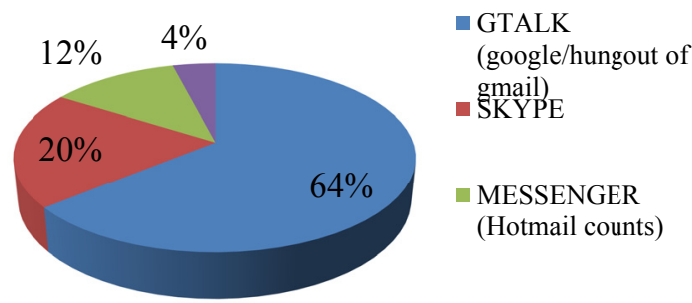

Figure 4. Used tools

\subsection{Assessment of the positive and negative heuristics}

In the table below we present a categorization of the positive and negative heuristics of students' responses as regards the experience in videotutoring.

Table 5. Positive and negative heuristics of students'

\begin{tabular}{ccc}
\hline CATEGORY & DESCRIPTORS & COUNTERS \\
\hline Utility-doubts & Enquiries, doubts, questions, benefit, productive & 8 \\
Atmosphere & Entertaining, enjoyable, good treatment, proximity & 5 \\
Comfort & Comfort, timetables, access to tutoring & 4 \\
Positive & Positive without specifying attributes & 4 \\
Novelty & Innovative, new, different & 3 \\
Presentations & Presentations performed without any pressure and in a quiet environment & 1 \\
& Total positive heuristics & $\mathbf{2 5}$ \\
CONECTIVITY- & Networks, technical difficulties & 3 \\
UNNECESSARY- & It is not necessary & 1 \\
TEACHER TRAINING- & Lack of teacher training & 1 \\
\end{tabular}

It is stressed that the ratio of positive statements is 5 to 1 , as opposed to negative statements. Among the positive aspects, we have to enhance its productive nature. Students value the experience to answer questions or solve practical issues. This positive character accumulates the third part of the statements: expressions such as "doubts are solved", "it is useful," "it clarifies things", etc.). The "Atmosphere" is cited in about $20 \%$ of the time ("it is fun," "we are relaxed") and "comfort" also achieves a high score.

There are four statements related in general to its positive value, which do not require anything about its characteristics or qualitative features ("It is fine", "I feel good", "it is good"). However, others simply highlight their interest in something they consider new and innovative.

Among the negative factors, we have to point out the technical difficulties listed three times. There also exists an interesting proposition related to the lack of real necessity and lack of technological training of teachers to carry out the experience.

\section{Discussion and conclusions}

Almost all learning experiences which are developed through the application of new technologies are at risk of being "dazzled by the brightness of such technological devices". We remain speechless as regards a technology we do not understand and we wonder whether it will be possible "to naturalize this strange situation" in order to apply it to learning. In this experience, we think we have overcome that dazzle we spoke about previously and have faced up to the challenge of experiencing and reflecting. Actually, it is possible to naturalize this situation. It is a means of relationship that will influence interpersonal relationships. Our early childhood education teachers work in schools equipped with cameras which let parents be in contact with their children during their working hours. Videoconferences are, in this sense, integrated into our lifestyle and relationships.

Taking into account the objectives we proposed at the beginning of this study- to experience in order to reflect, to evaluate the impact on learning and qualify students in the use of videoconference in their professional future-, 
we must highlight the complexity of this experience and its richness.

As we have observed, this is a methodological proposal which is accompanied by many related factors which have an important impact on the validity and effectiveness of this experience. We have proven that the categorization built is useful to describe and define problems and solutions. Technological, organizational and educational issues are intertwined in an experience that may seem simple, such as performing a tutoring through the use of videoconference. However, it is not a simple experience.

It has many aspects which can imply a risk of failure due to the necessary technological skills, the necessary human coordination, and the necessary pedagogical usefulness and motivation.

We have not only proven that this experience is viable and useful. We have also observed that for the younger generations it is also "natural". Our students use this means of synchronous audio-visual communication with relatives and friends. Therefore, the fact of making use of these resources is both a social requirement and a responsibility for the knowledge of our future teachers.

It is also of crucial importance to enhance the richness provided by this interdisciplinary experience to learning. The possibilities to share places among teachers and build common experiences have an impact on the improvement of education, on the improvement of coordination and the students' perception of their teachers. For example, when we deal with subjects that are offered in successive terms or semesters, the experience of the first videoconference will not be a punctual experience since some months later the students will perform again a videoconference to develop a group presentation.

With reference to the immediate impact on learning, we have proven that the resolution of problems in the academic context is the first feature emphasized by students as regards the use of videotutoring.

We still have new questions related to its long-term impact because we think it is necessary to perform an annual study related to the number of times that students have made use of this technology for academic purposes. We think this is a value that can influence the way in which the students organize to work in groups, what eventually requires collective discussion in spite of the fact that students have their own agendas which most of the times are difficult to coordinate. Therefore, new questions are posed to know if students incorporate this technology into their methods of study, that is to say, if this technology transforms their study habits.

\section{References}

Aguaded, J. I. (1996). Comunicación audiovisual en una enseñanza renovada. Huelva: Grupo Pedagógico Andaluz. Retrieved from https://www.researchgate.net/profile/Ignacio_Aguaded/publication/39146901_ Comunicacion_audiovisual_en_una_ensenanza_renovada_Propuestas_desde_los_medios/links/54422ed50c f2e6f0c0f6be81/Comunicacion-audiovisual-en-una-ensenanza-renovada-Propuestas-desde-los-medios.pdf

Ambròs, A. (2011). Educar en medios de comunicación: la educación mediática: 10 ideas clave. Barcelona: Graó.

Area, M., \& Guarro, A. (2013). Los entornos colaborativos en la formación online. In J. Ignacio Aguaded, Tecnologías y medios para la educación en la e-sociedad (pp. 211-238) Madrid: Alianza.

Barroso, J. y Cabero, J. (2013). Utilización educativa de la videoconferencia. In J. Barroso \& J. Cabero (Coords), Nuevos escenarios digitales. Las tecnologías de la información y la comunicación aplicadas a la formación $y$ desarrollo curricular (pp. 399-410). Madrid: Pirámide.

Bello, V. M., Sastre, W. J., \& Barreto, M. W. (2013). Experiencia Docente Iberoamericana sobre metodología de la Investigación a través de videoconferencia." @tic. Revista D'innovació Educativa 50-59. http://dx.doi.org/ 10.7203/attic.11.3050

Castillo-Olivares, J. M., Castro, F., \& Martínez, J. (2013). Detection of learning needs in the teaching staff regarding the use of a virtual campus at La Laguna University. Revista Procedia Social and behavioral Science 93, 1333-1336. https://doi.org/10.1016/j.sbspro.2013.10.039

HEFCE (2010). Effective Practice in a Digital Age: A guide to technology-enhanced assessment and feedback. London: JISC. Retrieved from http://www.jisc.ac.uk/media/documents/themes/elearning/effpraceassess.pdf

Henderson, M., \& Phillips, M. (2015). Video-based feedback on student assessment: scarily personal. Australasian Journal of Educational Technology, 31(1), 51-66. https://doi.org/10.14742/ajet.1878

Rodríguez, R., Hernández, J., \& González, C. (2006). Docencia Universitaria: Proyectos De Innovación Docente. Oviedo: Instituto De Ciencias De La Educación.

Marín, V. I., \& Salinas, J. (2015). Percepciones del feedback en vídeo por parte de estudiantes de un posgrado 
de educación online. Retrieved from: http://www.edutec.es/sites/default/files/congresos/edutec15/ARTICU LOS/PEI-Politicas_Educativas_y_de_Investigacion/vmarin_percepciones_feedback_video_estudiantes.pdf

Martínez, F. (2003). Redes de comunicación en la enseñanza: Las nuevas perspectivas del trabajo corporativo. Barcelona: Ed Paidós. Retrieved from http://revistas.usal.es/index.php/revistatesi/article/viewFile/14348/1 4734

Webster, S. (1998). Instrumentos para la formación: videoconferencias. Cuadernos de Documentación Multimedia. Servicio de Documentación Multimedia UCM. Retrieved from http://pendientedemigracion. ucm.es/info/multidoc/multidoc/revista/cuad6-7/susan.htm Última visita 25/04/2016.

\section{Copyrights}

Copyright for this article is retained by the author(s), with first publication rights granted to the journal.

This is an open-access article distributed under the terms and conditions of the Creative Commons Attribution license (http://creativecommons.org/licenses/by/4.0/). 